\title{
Conf-950740--49
}

\section{PREVENTION OF NON-DUCTILE FRACTURE IN 6061-T6 ALUMINUM NUCLEAR PRESSURE VESSELS ${ }^{\star}$}

\author{
G. T. Yahr \\ Engineering Technology Division \\ Oak Ridge National Laboratory \\ Oak Ridge, Tennessee 37831-8051
}

\begin{abstract}
The American Society of Mechanical Engineers (ASME) Boiler and Pressure Vessel Committee has approved rules for the use of 6061-T6 and 6061-T651 aluminum for the construction of Class 1 welded nuclear pressure vessels for temperatures not exceeding $149^{\circ} \mathrm{C}\left(300^{\circ} \mathrm{F}\right)$. Nuclear Code Case N-519 will allow the use of this aluminum in the construction of low temperature research reactors such as the Advanced Neutron Source. The rules for protection against non-ductile fracture are discussed. The basis for a value of $25.3 \mathrm{MPa} \sqrt{\mathrm{m}}$

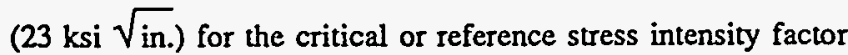
for use in the fracture analysis is presented. Requirements for consideration of the effects of neutron irradiation on the fracture toughness are discussed.
\end{abstract}

\section{INTRODUCTION}

Oak Ridge National Laboratory (ORNL) has proposed a new facility for neutron research, centered around a new research reactor, called the Advanced Neutron Source (ANS) (West, 1988; Harrington, 1991). The ANS is to be a user experimental facility for many scientific fields, including neutron scattering with cold, thermal, and hot neutrons (the most important scientific justification for the project); engineering materials irradiation; isotope production (including transuranium isotopes); materials analysis; and nuclear science. It is anticipated that the ANS will lead to important technological developments that will enhance our global competitiveness.

The user requirements, particularly the need for a large, accessible volume of a very high thermal neutron flux, determine the main features (high power [ $-300 \mathrm{MW}(t)]$ and small size) of the reactor core design. The basic concept is conventional: a heavy-water-cooled and reflected reactor.

The coolant inlet temperature is expected to be $45^{\circ} \mathrm{C}\left(113^{\circ} \mathrm{F}\right)$ and the bulk coolant outlet temperature is expected to be $85^{\circ} \mathrm{C}$ $\left(185^{\circ} \mathrm{F}\right)$. The inlet pressure will be $3.5 \mathrm{MPa}(508 \mathrm{psi})$. The primary pressure boundary around the reactor core is a long 0.5 $m$ (20 in.) diameter vessel with flanges on both ends so that it can be periodically replaced as required due to embrittlement caused by neutron irradiation. Outside the primary pressure boundary vessel, there will also be a $3.5 \mathrm{~m}(11.5 \mathrm{ft})$ diameter

* Research sponsored by the Office of Nuclear, U.S. Department of Energy under contract DE-AC05-84OR21400 with Martin Marietta Energy Systems, Inc. reflector tank with numerous penetrations and attachments that will contain heavy water at a pressure of about $0.5 \mathrm{MPa}$ (75 psig). The heavy water in the reflector tank will be at a temperature below $46^{\circ} \mathrm{C}\left(115^{\circ} \mathrm{F}\right)$.

The high nuclear-induced internal heat generation rate near the reactor core in the primary pressure boundary vessel, and the desire to preserve the maximum number of neutrons, led to the choice of aluminum as the primary pressure boundary material. Aluminum has been employed as a structural material in most research reactors. The aluminum alloy $6061-\mathrm{T} 6$ has been successfully used in structural applications in several research reactors including the High Flux Isotope Reactor (HFIR) at Oak Ridge and the High Flux Beam Reactor (HFBR) at Brookhaven National Laboratory. The HFBR reactor vessel is 6061-T6 aluminum. It was designed in accordance with the ASME Boiler and Pressure Vessel Code for Unfired Pressure Vessels, Section Vm (1959), including all revisions, addenda, and applicable code case rulings in effect at the date of award of the construction contract. In addition, critical areas of the vessel where discontinuity stresses could be appreciable were examined and analyzed in accordance with the document "Tentative Structural Design Basis for Reactor Pressure Vessels and Directly Associated Components" (1958) along with formulae from reports, documents and publications by Bijlaard, Horvay, Galletly, et al.

Previous Department of Energy (DOE) research reactors have not been required to be built according to the ASME Nuclear Code. However, DOE Order 5480.4 Environmental Protection, Safety, and Health Protection Standards (1984) specifically requires all DOE and DOE contractor operations to apply the ASME Boiler and Pressure Vessel Code to DOE-owned reactors. Therefore, it will be necessary that the materials of construction for the ANS, including 6061-T6 aluminum, be acceptable Code materials.

Code Case N-519 - "Use of 6061-T6 and 6061-T651 Aluminum for Class 1 Nuclear Components" (1994) was approved by the ASME Board on Nuclear Codes and Standards on April 7, 1994. Nuclear Code Case N-519 will allow the use of welded 6061-T6 aluminum in the construction of low temperature research reactors such as the ANS. The principal developments required for Code Case N-519 were fatigue curves and procedures for protection against non-ductile fracture. The fatigue curves were discussed in a previous paper (Yahr, 1993). The rules for protection against non-ductile fracture are

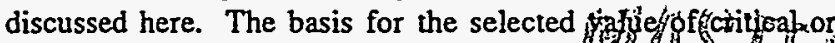

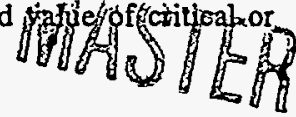




\section{DISCLAIMER}

Portions of this document may be illegible in electronic image products. Images are produced from the best available original document. 
reference stress intensity factor for use in the fracture analysis is presented. Requirements for consideration of the effects of neutron irradiation on the fracture toughness are discussed. Data from tests in the HFIR that show the effects of irradiation on 6061-T651 aluminum are discussed.

\section{ASME CODE APPROACH TO PREVENTION OF NON-DUCTILE FAILURE}

The ASME Boiler and Pressure Vessel Code, Section III, (1992), emphasizes the use of ductile materials for construction of Class 1 nuclear components. Article NB-2300 requires impact testing to assure that the materials used have adequate fracture toughness. Austenitic stainless steels and nonferrous material are exempt from impact test requirements.

Paragraph NB-321(d) further requires an evaluation of service and test conditions by methods similar to those contained in Appendix 6 except for piping, pump, and valve material. Appendix 6 is based on the fracture mechanics approach recommended by the Pressure Vessel Research Committee's Ad Hoc Task Group on Toughness Requirements (1972). Appendix $\mathrm{G}$ includes a curve in Fig. G-2210-1 that gives a lower bound value of the critical, or reference, stress intensity factor $K_{I R}$ as a function of a temperature which is related to the reference nil ductility temperature determined by impact testing. The curve is applicable to ferritic steels with a specified minimum strength of $34 \mathrm{MPa}(50.0 \mathrm{ksi})$ or less at room temperature, and may be used for materials which have specified minimum yield strengths at room temperature up to $621 \mathrm{MPa}$ (90.0) $\mathrm{ksi}$ provided data are included in the Design Specification that demonstrate that the toughness of the material lies above the curve in Fig. G-2210-1 even after radiation. Appendix G requires that one postulate a sharp surface defect normal to the direction of normal stress that has a depth of one-fourth of the section thickness and a length of 1.5 times the section thickness. For sections less than 102-mm (4-in.) thick, the 25.4-mm (1-in.) deep defect is conservatively postulated. Smaller defect sizes may be used on an individual case basis if a smaller size of maximum postulated defect can be ensured. In order to assure that brittle fracture will not occur for service level $A$ and $B$ loadings, the sum of twice the calculated stress intensity factor produced by primary stresses plus the stress intensity factor due to a thermal gradient through the thickness must not exceed the critical, or reference, stress intensity factor KIR.

\section{UNIRRADIATED FRACTURE BEHAVIOR OF 6061- T6 ALUMINUM}

Aluminum alloys, including 6061-T6, have a face-centeredcubic crystal structure. Under normal circumstances facecentered-cubic crystal structures do not exhibit cleavage fractures even at very low temperatures (Broek, 1986) (Barsom and Rolfe, 1987). The fracture mode is the same no matter what the temperature. Thus, the transition temperature phenomenon that is common to pressure vessel steels does not exist in aluminum alloys (Zinkham and Dedrick, 1969). Unlike steels, aluminum alloys exhibit toughness values at cryogenic temperatures that are about the same as at room-temperature.

Another characteristic of aluminum alloys is that they are rate insensitive (Broek, 1986) (Barsom and Rolfe, 1987). Thus, unlike pressure vessel steels, there is little difference in the value of $\mathrm{K}_{\mathrm{Ic}}$ determined from tests at slow loading rates and the value of $K_{\text {Id }}$ determined from tests at impact or dynamic loading rates.

The fracture toughness data in Table 1 from over 185 tests were collected from sixteen sources (Chu and Wacker, 1972) (Albertin and DeMastry, 1972) (Nelson and Kaufman, 1973) (Nelson and Brownhill, 1977) (Barker, 1979) (Alexander, 1993) (Structural Alloys Handbook, 1989)(MIL-HDBKSD, 1984) (MCIC-HB-04, 1977) (Schwarmann, 1988) (Aerospace Structural Metals Handbook, 1973) (ALFRAC, 1993) (McConnell et al., 1986) (Kapp, 1985) (Succop and Brown, 1977) (Shannon et al., 1977). The product forms included plates from $12.7-\mathrm{mm}$ to $127-\mathrm{mm}$ thick, $63.5 \mathrm{~mm}$ diameter bar and various sizes of forgings. Weldments using either 4043 or 5356 weld rods were tested in both the as-welded condition and after post weld heat-treatment. Test temperatures ranged from $-196^{\circ} \mathrm{C}$ to $150^{\circ} \mathrm{C}$, but most tests were conducted at room temperature.

A large number of tests did not meet the validity requirements given in the appropriate ASTM standard. Data from almost 100 tests were reported in the literature as $\mathrm{K}_{\mathrm{Ic}}$ values. The minimum value reported for $\mathrm{KIc}$ was $23.1 \mathrm{MPa} \sqrt{\mathrm{m}}(21 \mathrm{ksi} \sqrt{\mathrm{in}}$ ) for specimens tested at room temperature with the crack oriented in the S-L direction. The key to the crack orientation is given in Figs. 1-3 (ASTM Spec. E399, 1990) (Chu and Wacker, 1972). As can be seen in Fig. 1, crack propagation in the S-L orientation is not likely to occur in a pressure vessel. The lowest value reported for $\mathrm{K}_{\mathrm{Ic}}$ for any orientation that could potentially occur in a pressure vessel was $25.3 \mathrm{MPa} \sqrt{\mathrm{m}} \quad(23$ $\mathrm{ksi} \sqrt{\mathrm{in}}$.). This value was measured at room temperature on a 4043 weld in $76.2 \mathrm{~mm}$ ( 3 in.) thick plate without any post-weld heat-treatment. The average room temperature $\mathrm{K}_{\mathrm{Ic}}$ value was

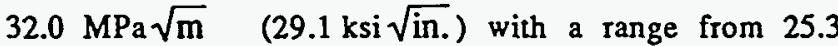
$\mathrm{MPa} \sqrt{\mathrm{m}}$ (23 ksi $\sqrt{\mathrm{in} .}$ ) to $36.3 \mathrm{MPa} \sqrt{\mathrm{m}} \quad(33.0 \mathrm{ksi} \sqrt{\mathrm{in} .}$ ) if the data from specimens with the crack in the S-L orientation are excluded.

Data from tests that did not meet the ASTM requirements for a valid $\mathrm{K}_{\text {Ic }}$ value were generally reported as $\mathrm{K}_{\mathrm{q}}$. The average $\mathrm{K}_{\mathrm{q}}$ value at room temperature was $32.3 \mathrm{MPa} \sqrt{\mathrm{m}} \quad(39.4 \mathrm{ksi} \sqrt{\mathrm{in} .})$ with a range from $26.9 \mathrm{MPa} \sqrt{\mathrm{m}} \quad(24.5 \mathrm{ksi} \sqrt{\text { in.) }}$ to 44.4 $\mathrm{MPa} \sqrt{\mathrm{m}}$ (40.4 ksi $\sqrt{\mathrm{in} .})$. This agrees well with the $\mathrm{K}_{\mathrm{Ic}}$ data. Alexander reported his data as $K_{j}$ which averaged 33.1 $\mathrm{MPa} \sqrt{\mathrm{m}}$ (30.2 ksi $\sqrt{\mathrm{in}}$.).

The fracture toughness is slightly lower at temperatures above room temperature and higher at temperatures below room temperature. Alexander's data shows that $\mathrm{K}_{\mathrm{j}}$ averaged 33.1 $\mathrm{MPa} \sqrt{\mathrm{m}} \quad(30.1 \mathrm{ksi} \sqrt{\mathrm{in}}$ ), $30.3 \mathrm{MPa} \sqrt{\mathrm{m}}$ (27.6 ksi $\sqrt{\mathrm{in} .})$ and $32.1 \mathrm{MPa} \sqrt{\mathrm{m}}(29.2 \mathrm{ksi} \sqrt{\mathrm{in} .})$ at room temperature, $95^{\circ} \mathrm{C}$ and $150^{\circ} \mathrm{C}$ respectively. Values of $\mathrm{KIc}$ at cryogenic temperatures of $-196^{\circ} \mathrm{C}$ and $-78^{\circ} \mathrm{C}$ averaged $39.1 \mathrm{MPa} \sqrt{\mathrm{m}}$ 


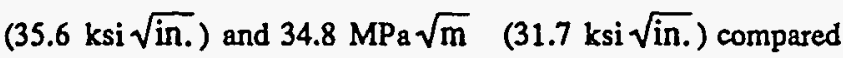
to the room temperature average of $32.0 \mathrm{MPa} \sqrt{\mathrm{m}}$ (29.1 ksi $\sqrt{\text { in. }) \text {. }}$

A value of $25.3 \mathrm{MPa} \sqrt{\mathrm{m}}(23.0 \mathrm{ksi} \sqrt{\mathrm{in}}$ ) is the critical, or reference, stress intensity value, $\mathrm{K}_{\mathrm{IR}}$ that is specified in Code Case N-519. The only reported values that are lower were for the S-L orientation in plates. Because the stresses that would drive a crack in that orientation do not usually occur in pressure vessels, it is reasonable not to base the value of $K_{I R}$ on those data.

\section{IRRADIATED FRACTURE TOUGHNESS}

The mechanism for irradiation damage in many materials, including pressure vessel steels, is displacement of atoms in the crystal lattice due to collisions with high energy neutrons. Thus, changes in toughness of steels are usually correlated with the fast fluence. Aluminum is transmuted to silicon by thermal neutrons. These silicon atoms are the principal hardening mechanism in aluminum alloys. The effect of irradiation on the tensile behavior of 6061-T6 aluminum is documented in the literature (Farrell and King, 1979)(Weeks et al., 1990). The yield and tensile strength are increased by irradiation and the tensile ductility is decreased. Charpy impact tests on highly irradiated 6061-T6 aluminum show a marked decrease in the impact strength (Weeks et al., 1993). Estimates from Weeks' Charpy data by Kassir (1989) indicated that the unirradiated value of $\mathrm{K}_{\mathrm{Ic}}$ was $21.75 \mathrm{MPa} \sqrt{\mathrm{m}}$ and that the value dropped to 8.7 $\mathrm{MPa} \sqrt{\mathrm{m}}$ after irradiation to a thermal neutron fluence of $4.2 \times 10^{27} \mathrm{~m}^{-2}$.

Albertin and DeMastry (1972) measured the effect of irradiation at cryogenic temperatures to a maximum fast fluence of $1.4 \times 10^{22} \mathrm{~m}^{-2}$. Those test results are given in Table 2 . There is no appreciable effect of irradiation at this low fluence.

Alexander (1993) has conducted J-integral-resistance (JR) curve toughness tests on inadiated and unimadiated $0.45 \mathrm{~T}$ compact specimens (28.6 $\times 27.4 \times 11.4-\mathrm{mm}$ thick) of 6061 T651 aluminum plate. The specimens were irradiated to a maximum thermal neutron fluence of $1 \times 10^{26} \mathrm{~m}^{-2}$. The minimum thermal neutron fluence was forty percent of the peak fluence. The fast neutron fluence was half the thermal neutron fluence. The specimen temperature during the irradiation was in the range of $60^{\circ} \mathrm{C}$ to $114^{\circ} \mathrm{C}$. Tests were conducted at room temperature, $95^{\circ} \mathrm{C}$, and $150^{\circ} \mathrm{C}$. The results are shown in Table 2. There is no degradation of the fracture toughness at $25^{\circ} \mathrm{C}$ or $95^{\circ} \mathrm{C}$, and only a slight decrease at $150^{\circ} \mathrm{C}$.

\section{REQUIREMENTS FOR CONSIDERATION OF IRRADIATION EFFECTS}

Code Case N-519 includes the following requirement to assure that components are removed from service before neutron irradiation reduces the fracture toughness enough to compromise their structural integrity.

"This material is known to be susceptible to embrittlement as a result of neutron irradiation. When the component will be subjected to neutron irradiation during service, the Design Specification shall include requirements for consideration of the effects of neutron irradiation on the fracture toughness and requirements for replacement of components before they pose a hazard for brittle fracture. The designer shall establish the irradiated KIR value. That value shall be used to determine when components must be replaced. An inservice surveillance program, similar to the one given in ASTM E 185-82 for light-water cooled nuclear power reactor vessels, shall be established to monitor the embrittlement of the reactor vessel material. If data from surveillance tests indicate that the established $K_{I R}$ value is unconservative, the component replacement schedule must be modified appropriately. The designer shall ensure that loss of ductility in-service does not invalidate the $3 S_{m}$ limit on the range of primary plus secondary stress."

Alexander is extending his irradiation tests to thermal fluences of $8 \times 10^{26} \mathrm{~m}^{-2}$ and to include weldments. These data will be used to establish an irradiated $\mathrm{K}_{\text {IR }}$ value for the ANS design and establish planned schedules for replacement of 6061-T651 components. Preliminary planning of a surveillance program for the ANS has been done by Heavilin (1995). A preliminary fracture analysis of the ANS core pressure boundary tube has been done by Schulz (1995).

\section{SUMMARY}

Code Case N-519 allows the use of 6061-T6 and 6061-T651 aluminum in the construction of Section III. Division 1, Class 1 welded pressure vessels at temperatures not exceeding $149^{\circ} \mathrm{C}$ $\left(300^{\circ} \mathrm{F}\right)$. The two major developments necessary for this Code Case were fatigue curves and procedures for protection against non-ductile fracture. The basis for the fatigue curves was presented earlier (Yahr, 1993). The basis for the rules for protection against non-ductile rupture have been presented here. A single value of $25.3 \mathrm{MPa} \sqrt{\mathrm{m}}(23.0 \mathrm{ksi} \sqrt{\text { in. })}$ for the critical, or reference, stress intensity factor $K_{I R}$ is used in an Appendix $G$ type analysis instead of the temperature-dependent values given in Fig. G-2210-1 of the Code for steels.

Because of a potential decrease in fracture toughness of 6061 T6 aluminum due to neutron irradiation, the designer must establish an irradiated $\mathrm{K}_{\mathrm{IR}}$ value that will exceed the materials fracture toughness at the end of life and show that non-ductile fracture will not occur if the fracture toughness does not fall below that value of $\mathrm{K}_{\mathrm{IR}}$. An in-service surveillance program must be established to monitor the irradiation-induced embrittlement of the vessel material. If the measured fracture toughness of the surveillance tests indicates that the established $\mathrm{K}_{\mathrm{IR}}$ value is not conservative, the component must be removed from service.

It should be noted that Code Case N-519 applies only to 6061 $\mathrm{T} 6$ aluminum. Limited data in the literature suggest that some other aluminum alloys, in particular 5000 series aluminum. retain much lower tensile ductility than 6061-T6 aluminum. The ductility of 6061-T6 aluminum was a major concem to several Code Committee members so materials with less ductility would deserve critical evaluation. 


\section{ACKNOWLEDGEMENTS}

Helpful discussions with J. G. Merkle and K. C. Schulz are gratefully acknowledged. Members of the ASME Boiler and Pressure Vessel Committee's Subgroup on Materials, Fabrication, and Examination (SCII) chaired by R. M. Jessee, the Subgroup on Design (SCIII) chaired by R. W. Barnes and the Subgroup on Toughness chaired by R. K. Nanstad provided valuable guidance and many helpful suggestions. The support of this work by J. M. Corum, D. L. Selby and C. D. West is gratefully acknowledged. I thank Rhonda Baxter for typing the manuscript.

\section{REFERENCES}

Aerospace Structural Metals Handbook, Vol. 3, Belfour Stulen. Inc., 1973.

Albertin, L. and DeMastry, J., "Post-Irradiation Tensile and Fracture Toughness Properties of 6061-T651 Aluminum Plate," Astronuclear Program Report, Westinghouse Electric Co., Pittsburgh, PA, 1972.

Alexander, D. J., "The Effect of Irradiation on the Mechanical Properties of 6061-T651 Aluminum," Effects of Radiation on Materials: 16th International Symposium, ASTM STP 1175, American Society for Testing and Materials, January 1, 1993.

ALFRAC, Aluminum Fracture Toughness Database, An MPD Network File, STN International, Columbus, Ohio, 1993.

"ASME Boiler and Pressure Vessel Code Section VIII, Rules for Construction of Unfired Pressure Vessels," 1959 Edition, ASME, 1959.

ASME Boiler and Pressure Vessel Committee, "ASME Boiler and Pressure Vessel Code, Section III: Rules for Construction of Nuclear Power Plant Components, Division I," The American Society of Mechanical Engineers, New York, New York, 1992.

Barker, L. M., "Theory for Determining $\mathrm{K}_{\mathrm{Ic}}$ from Small, NonLEFM Specimens, Supported by Experiments on Aluminum," International Journal of Fracture, 15, pp. 515-536, 1979.

Barsom, J. M. and Rolfe, S. T., "Fracture and Fatigue Control in Structures: Applications in Fracture Mechanics," PrenticeHall, Inc. Englewood Cliffs, New Jersey, 1987.

Broek, D., "Elementary Engineering Fracture Mechanics, Kluwer Academic Publishers, Dordrecht, The Netherlands, 1986.

"Case N-519, Use of 6061-T6 and 6061-T651 Aluminum for Class 1 Nuclear Components, Section III, Division 1," Supplement 10 to 1992 Edition, 1994.
Chu, H. P. and Wacker, G. A., "Fracture Toughness and Stress Corrosion Properties of Aluminum Alloy Hand Forgings," Journal of Materials, JMLSA, Vol. 7, No. 1, pp. 95-99. March 1972.

DOE Order 5480.4, Environmental Protection, Safety, and health Protection Standards, May 15, 1984.

Farrell, K. and King, R. T., "Tensile Properties of NeutronIrradiated 6061 Aluminum Alloy in Annealed and PrecipitationHardened Conditions," Effects of Radiation on Structural Materials, ASTM STP 683, J. A. Sprague and D. Kramer, (eds.), American Society for Testing and Materials, pp. 440449, 1979.

Handbook on Materials for Superconducting Machinery, MCIC-HB-04, Metals and Ceramics Information Center, Battelle, Columbus, Ohio, January 1977.

Harrington, R. M., "Designing for Safety in the Conceptual Design of the Advanced Neutron Source," Nuclear Safety, Vol. 32, No. 2, April-June 1991.

Heavilin, S. M., Advanced Neutron Source Materials Surveillance Program, ORNL/M-3733, Oak Ridge National Laboratory, Oak Ridge, Tennessee, January 1995.

Kapp, J. A., "J-R Curve Determination Using Precracked Charpy Specimens and the Load-Drop Method for Crack Growth Measurements," Fracture Mechanics: Sixteenth Symposium, ASTM STP 868, M. F. Kanninen and A. T. Hopper, (eds.), American Society for Testing and Materials, Philadelphia, pp. 281-292, 1985.

Kassir, M. T., Brookhaven National Laboratory Structural Analysis Division, "Fracture Mechanics Evaluation of the HFBR Beam Tubes," Report to the BNL Reactor Division, August 1989.

McConnell, P., Scheckherd, J. W., Perrin, J. S., and Wullaert, R. A., "Experience in Subsized Specimen Testing," The Use of Small-Scale Specimens for Testing Irradiated Material, ASTM STP 888, W. R. Corwin and G. E. Lucas, (eds.), American Society for Testing and Materials, Philadelphia, pp. 353-368, 1986.

Military Standardization Handbook, Metallic Materials and Elements for Aerospace Vehicle Structures, Vol. 1, MILHDBK-5D, January 1, 1984.

Nelson, F. G. and Brownhill, D. J., "Fracture Characteristics of Plain and Welded 3-In.-Thick Aluminum Alloy Plate at Various Temperatures," Flaw Growth and Fracture, ASTM STP 631, American Society for Testing and Materials, pp. 285-309. 1977.

Nelson, F. G. and Kaufman, J. G., "Fracture Toughness of Plain and Welded 3-In.-Thick Aluminum Alloy Plate," Progress in 
Flaw Growth and Fracture Toughness Testing, ASTM STP 536, American Society for Testing and Materials, pp. 350-376, 1973.

PVRC Ad Hoc Task Group on Toughness Requirements, "PVRC Recommendations on Toughness Requirements for Ferritic Materials," Welding Research Council WRC Bulletin 175, August 1972.

Schulz, K. C., "Preliminary Fracture Analysis of the Core Pressure Boundary Tube (CPBT) for the Advanced neutron Source (ANS) Research Reactor," to be published as ORNL/TM report.

Schwarmann, L., Material Data of High-Strength Aluminum Alloys for Durability Evaluation of Structures, Fatigue Strength, Crack Propagation, and Fracture Toughness, Aluminium-Verlag, Dusseldorf, 1988.

Shannon, J. L. Jr., Donald, J. K., and Brown, W. F. Jr., "Heavy-Section Fracture Toughness Screening Specimen," Developments in Fracture Mechanics Test Methods Standardization, ASTM STP 632, W. F. Brown, Jr., and J. G. Kaufman, (eds.), American Society for Testing and Materials, pp. 96-114, 1977

"6061 Aluminum," Structural Alloys Handbook, Vol. 3, Battelle, Columbus, Ohio, 1989.

"Standard Test Method for Plane-Strain Fracture Toughness of Metallic Materials," ASTM Standard E 399-90, American Society for Testing and Materials, 1990.

Succop, G. and Brown, W. F., Jr. "Estimation of KIc From Slow Bend Precracked Charpy Specimen Strength Ratios," in Developments in Fracture Mechanics Test Methods Standardization, ASTM STP 632, W. F. Brown, Jr. and J. G. Kaufman, (eds.), American Society for Testing and Materials, Philadelphia, pp. 281-292, 1985.

"Tentative Structural Design Basis for Reactor Pressure Vessels and Directly Associated Components (Pressurized, Water Cooled Systems)," 1 December 1958 Revision, U. S. Department of Commerce, OTS Document No. PB151987.

Weeks, J. R., Czajkowski, C. J., and Tichler, P. R., "Effects of High Thermal and High Fast Fluences on the Mechanical Properties of Type 6061 Aluminum in the HFBR," Effects of Radiation on Materials: 14th International Symposium (Volume II), ASTM STP 1046, N. H. Packan, R. B. Stoller, and A. S. Kumar, (eds.), American Society for Testing and Materials, Philadelphia, pp. 441-452, 1990.

Weeks, J. R., Czajkowski, C. J., and Farrell, K., "Effects of High Thermal Neutron Fluences on Type 6061 Aluminum," Effects of Radiation on Materials: 16th International Symposium, ASTM STP 1175, A. S. Kumar, D. S. Gelles, R. K.
Nanstad, and E. A. Little, (eds.), American Society for Testing and Materials, Philadelphia, 1993.

West, C. D., "Overview of the ANS Project," Transactions American Nuclear Society, 57, pp. 288-289, 1988.

Yahr, G. T., "Fatigue Design Curves for 6061-T6 Aluminum," Codes and Standards in a Global Environment, James E. Staffiern, (ed.), PVP-Vol. 259, ASME, pp. 43-49, 1993.

Zinkham, R. E. and Dedrick, J. H., "Fracture Behavior of Aluminum Alloys," Fracture, An Advanced Treatise, Vol. VI, Fracture of Metals, Academic Press, pp. 299-370, 1969.

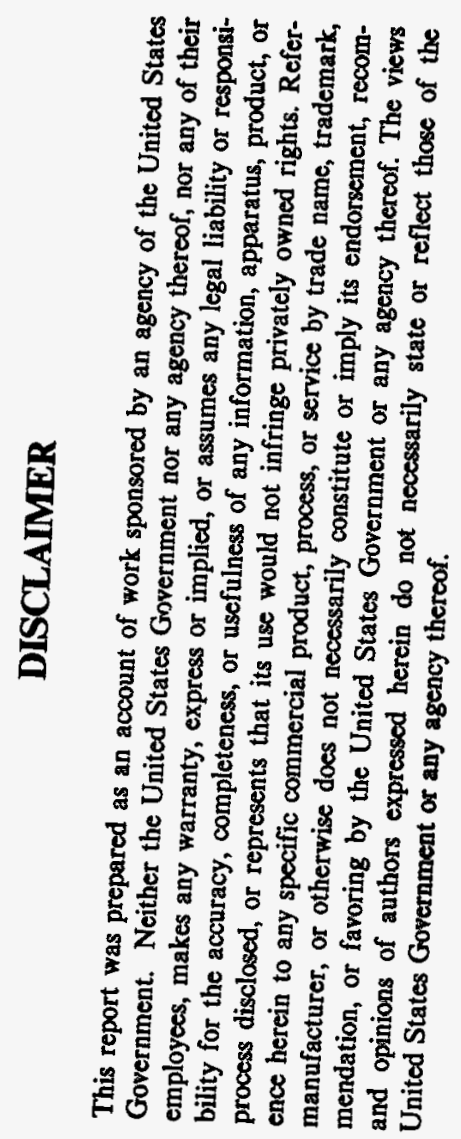


TABLE 1. FRACTURE TOUGHNESS DATA FOR 6061-T6, 6061-T651, AND 6061-T652 ALUMINUM.

\begin{tabular}{|c|c|c|c|c|c|c|c|c|c|c|c|}
\hline Material & $\begin{array}{c}\text { Temp. } \\
\text { (C) }\end{array}$ & $\begin{array}{c}\text { Specimen } \\
\text { Type }\end{array}$ & $\begin{array}{c}\text { Specimen } \\
\text { Sizo } \\
\text { (mm) }\end{array}$ & $\begin{array}{l}\text { Crack } \\
\text { Or. }\end{array}$ & $\begin{array}{c}\text { No. } \\
\text { of } \\
\text { Spec. }\end{array}$ & $\begin{array}{c}\mathrm{Kq} \\
(M \mathrm{~Pa} \sqrt{\mathrm{m}})\end{array}$ & $\frac{\operatorname{Kmax}}{(\operatorname{MPa} \sqrt{\mathrm{m}})}$ & $\begin{array}{c}\mathrm{KJ} \\
(\mathrm{MPa} \sqrt{\mathrm{m}})\end{array}$ & $\begin{array}{c}\mathrm{Klc} \\
(\mathrm{MPa} \sqrt{\mathrm{m}})\end{array}$ & Notes & Referenco \\
\hline 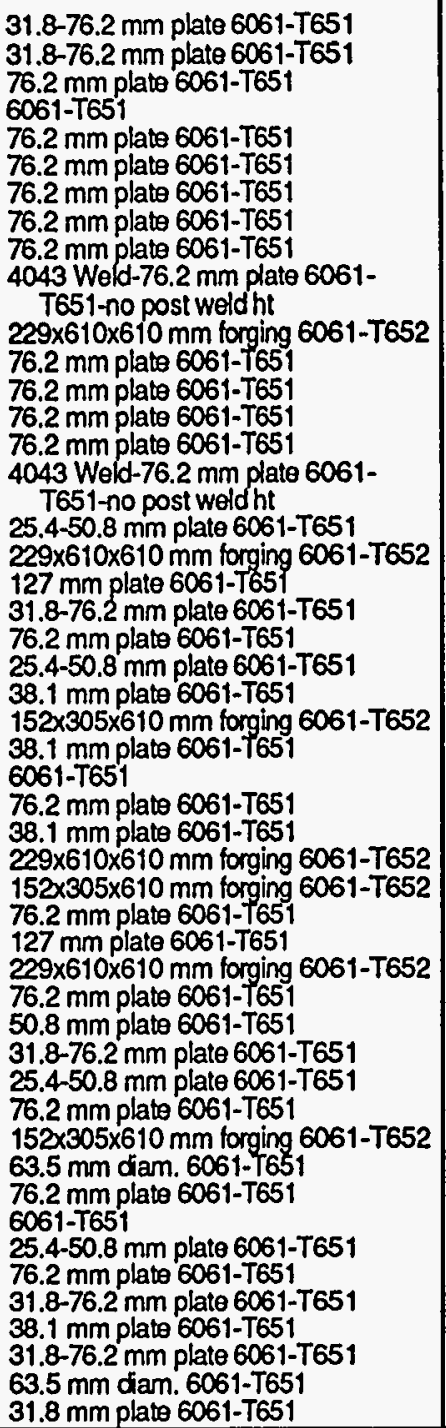 & \begin{tabular}{l|}
24 \\
24 \\
22 \\
22 \\
22 \\
22 \\
22 \\
-73 \\
22 \\
22 \\
24 \\
22 \\
-196 \\
-73 \\
-73 \\
24 \\
22 \\
24 \\
24 \\
24 \\
24 \\
22 \\
-196 \\
24 \\
22 \\
22 \\
22 \\
24 \\
22 \\
22 \\
24 \\
24 \\
-78 \\
24 \\
22 \\
22 \\
-196 \\
-78 \\
-196 \\
24 \\
-80 \\
24 \\
22 \\
24 \\
\end{tabular} & $\begin{array}{l}\text { Compact } \\
\text { Compact } \\
\text { Compact } \\
\text { Compact } \\
\text { UPE estimate } \\
\text { UPE estimate } \\
\text { UPE estimate } \\
\text { Notch-bend } \\
\text { Compact } \\
\text { Compact } \\
\text { Compact } \\
\text { UPE estimate } \\
\text { UPE estimate } \\
\text { Notch-bend } \\
\text { Notch-bend } \\
\text { Compact } \\
\text { Compact } \\
\text { Notch-bend } \\
\text { Notch-bend } \\
\text { Notch-bend } \\
\text { Notch-bend } \\
\text { UPE estimate } \\
\text { Notch-bend } \\
\text { Notch-bend } \\
\text { Compact } \\
\text { Compact } \\
\text { Notch-bend } \\
\text { UPE estimate } \\
\text { Notch-bend } \\
\text { Notch-bend } \\
\text { Compact } \\
\text { Notch-bend } \\
\text { Short rod } \\
\text { Compact } \\
\text { Notch-bend } \\
\text { UPE estimate } \\
\\
\text { Short rod } \\
\text { Compact } \\
\text { U. }\end{array}$ & $\begin{array}{c}25.4 \\
31.75 \\
76 \\
32 \\
\\
\\
25.4 \\
50.80 \\
30.5-76.2 \\
63.37 \\
38.1 \\
17.8 \\
25.4 \\
\\
\\
25.4 \\
17.8 \\
76 \\
6.55 \\
25.4 \\
25.4 \\
30.5 .76 .2 \\
31.75 \\
17.8 \\
38.1 \\
76 \\
\\
25.4-76.2 \\
25.477 .2 \\
22 \\
30.94 \\
\end{array}$ & 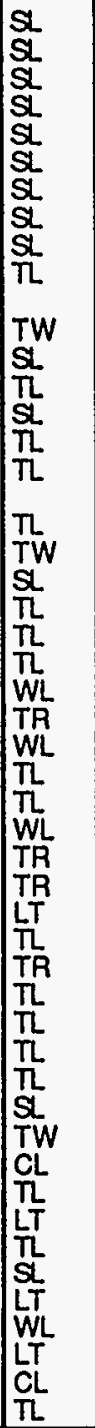 & $\begin{array}{l}1 \\
1 \\
1 \\
1 \\
3 \\
4 \\
1 \\
1 \\
1 \\
7\end{array}$ & $\begin{array}{l}23.2 \\
23.4 \\
23.7\end{array}$ & $\begin{array}{l}23.5 \\
23.8 \\
24.0 \\
24.0\end{array}$ & & $\begin{array}{l}23.1 \\
23.1 \\
23.2 \\
23.4 \\
23.4 \\
23.4 \\
23.7 \\
24.2 \\
25.3 \\
25.3 \\
25.7 \\
26.3 \\
26.4 \\
26.6 \\
27.5 \\
27.5 \\
27.8 \\
27.9 \\
28.0 \\
28.6 \\
28.7 \\
29.0 \\
29.1 \\
29.2 \\
29.2 \\
29.4 \\
29.7 \\
29.7 \\
29.8 \\
29.8 \\
30.4 \\
30.5 \\
30.5 \\
30.8 \\
30.8 \\
30.8 \\
30.8 \\
31.0 \\
31.8 \\
32.5 \\
32.7 \\
32.9 \\
32.9 \\
33.0 \\
33.0 \\
33.0 \\
34.1 \\
34.1 \\
34.3\end{array}$ & $\begin{array}{l}\text { MIN } \\
\text { MIN } \\
\text { AVG }\end{array}$ & $\begin{array}{l}\text { MIL-HDBK-5D } \\
\text { MIL-HDBK-5D } \\
\text { Nelson \& Kautman } \\
\text { Schwamann } \\
\text { Nelson \& Kautman } \\
\text { Nelson \& Brownhill } \\
\text { Nelson \& Kaufman } \\
\text { Nelson \& Brownhill } \\
\text { Nelson \& Brownhill } \\
\text { Nelson \& Brownhill } \\
\text { Chu \& Wacker } \\
\text { ALFRAC } \\
\text { Nelson \& Brownhill } \\
\text { Nelson \& Brownhill } \\
\text { Nelson \& Brownhill } \\
\text { Nelson \& Brownhill } \\
\text { MCIC-HB-O4 } \\
\text { Chu \& Wacker } \\
\text { ALFRAC } \\
\text { MIL-HDBK-5D } \\
\text { ALFRAC } \\
\text { MCIC-HB-O4 } \\
\text { Structural Alloys Hbk. } \\
\text { Chu \& Wacker } \\
\text { Structural Alloys Hbk. } \\
\text { Schwamann } \\
\text { Nelson \& Brownhill } \\
\text { ASMH } \\
\text { Chu \& Wacker } \\
\text { Chu \& Wacker } \\
\text { Nelson \& Brownhill } \\
\text { ALFRAC } \\
\text { Chu \& Wacker } \\
\text { Nelson \& Brownhill } \\
\text { Shannon, et al. } \\
\text { MIL-HDBK-5D } \\
\text { MCIC-HB-04 } \\
\text { ALFRAC } \\
\text { Chu \& Wacker } \\
\text { Barker } \\
\text { Nelson \& Brownhill } \\
\text { Schwammann } \\
\text { MCIC-HB-O4 } \\
\text { Nelson \& Brownhill } \\
\text { MlL-HDBK-5D } \\
\text { ASMH } \\
\text { MIL-HDBK-5D } \\
\text { Barker } \\
\text { ALFRAC } \\
\text { ALF }\end{array}$ \\
\hline
\end{tabular}


TABLE 1. FRACTURE TOUGHNESS DATA FOR 6061-T6, 6061-T651, AND 6061-T652 ALUMINUM. (CONT.)

\begin{tabular}{|c|c|c|c|c|c|c|c|c|c|c|c|}
\hline Material & $\begin{array}{c}\text { Temp. } \\
\text { (C) }\end{array}$ & $\begin{array}{l}\text { Specimen } \\
\text { Type }\end{array}$ & $\begin{array}{c}\text { Specimen } \\
\text { Sizo } \\
(\mathrm{mm})\end{array}$ & $\begin{array}{l}\text { Crack } \\
\text { Orr. }\end{array}$ & $\begin{array}{c}\text { No. } \\
\text { of } \\
\text { Spec. }\end{array}$ & $\frac{K q}{(M P a \sqrt{m})}$ & $\begin{array}{c}\mathrm{Kmax} \\
(\mathrm{MPa} \sqrt{\mathrm{m}})\end{array}$ & $\begin{array}{c}\mathrm{KJ} \\
(M P a \sqrt{\mathrm{m}})\end{array}$ & $\begin{array}{c}\mathrm{Klc} \\
(\mathrm{MPa} \sqrt{\mathrm{m}})\end{array}$ & Notes & Reference \\
\hline 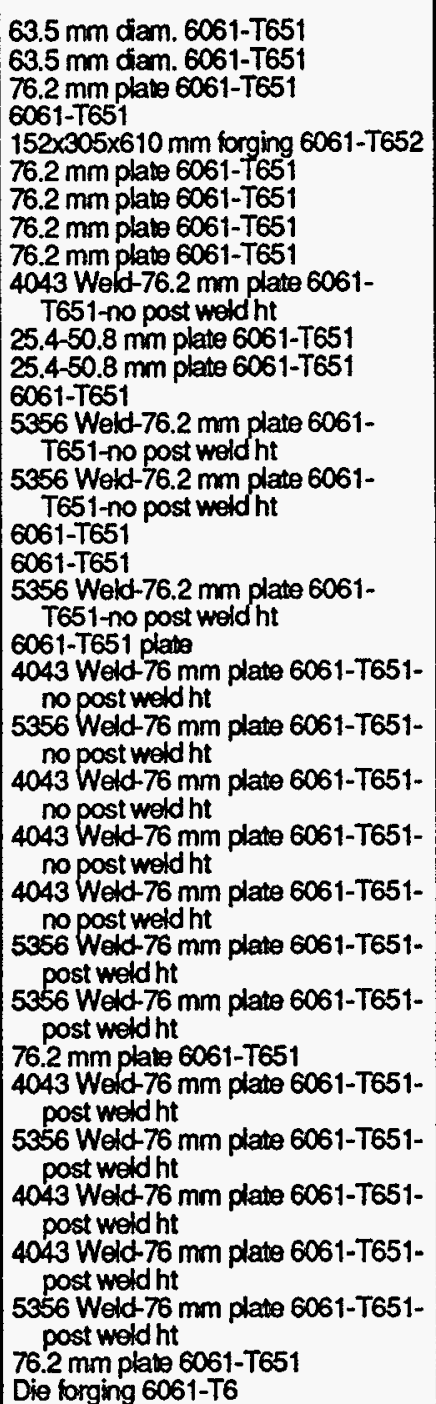 & $\begin{array}{l}22 \\
22 \\
22 \\
27 \\
22 \\
24 \\
-73 \\
-196 \\
-196 \\
-196 \\
-196 \\
-196 \\
-196 \\
22 \\
-73 \\
-84 \\
-196 \\
-196 \\
24 \\
22 \\
22 \\
22 \\
22 \\
22 \\
22 \\
22 \\
22 \\
22 \\
22 \\
22 \\
22 \\
22 \\
24 \\
24\end{array}$ & $\begin{array}{l}\text { Short rod } \\
\text { Short rod } \\
\text { UPE estimate } \\
\text { Compect } \\
\text { Notch-bend } \\
\text { Compact } \\
\text { UPE estimate } \\
\text { Compact } \\
\text { UPE estimate } \\
\text { UPE estimate } \\
\text { Notch-bend } \\
\text { Norch-bend } \\
\text { Compect } \\
\text { UPE estimate } \\
\text { UPE estimate } \\
\text { Compact } \\
\text { Compact } \\
\text { UPE estimate } \\
\text { Precracked Charpy } \\
\text { Norch-bend } \\
\text { Norch-bend } \\
\text { Notch-bend } \\
\text { North-bend } \\
\text { Notch-bend } \\
\text { Noxch-bend } \\
\text { Notch-bend } \\
\text { Compact } \\
\text { Norch-bend } \\
\text { Notch-bend } \\
\text { Norch-bend } \\
\text { Notch-bend } \\
\text { Norch-bend } \\
\text { Compact } \\
\text { Compact }\end{array}$ & $\begin{array}{l}25.4 \\
\\
25.4 \\
25.4 \\
\\
73.1 \\
73.1 \\
73.1 \\
73.1 \\
73.1 \\
73.8 \\
73.8 \\
63.5 \\
74.2 \\
73.7 \\
74.5 \\
74.7 \\
74.8 \\
74.96 \\
12.67\end{array}$ & $\begin{array}{l}\mathrm{CL} \\
\mathrm{CL} \\
\mathrm{LT} \\
\mathrm{TW} \\
\mathrm{LT} \\
\mathrm{LT} \\
\mathrm{LT} \\
\mathrm{LT} \\
\mathrm{TL} \\
\mathrm{TL} \\
\mathrm{TL} \\
\mathrm{TL} \\
\mathrm{TL}\end{array}$ & $\begin{array}{l}1 \\
1 \\
1 \\
1 \\
1 \\
1 \\
1 \\
1 \\
1 \\
1 \\
1 \\
1\end{array}$ & $\begin{array}{l}19.8 \\
20.4 \\
21.5 \\
21.8 \\
21.9 \\
23.1 \\
23.2 \\
23.3 \\
23.4 \\
24.2 \\
24.4 \\
25.5 \\
26.5 \\
26.9 \\
27.1\end{array}$ & $\begin{array}{l}32.6 \\
53.3 \\
35.6 \\
36.8 \\
34.9 \\
32.9 \\
33.3 \\
24.3 \\
34.1 \\
34.1 \\
33.2 \\
29.7 \\
30.1\end{array}$ & 51.9 & $\begin{array}{l}34.5 \\
34.7 \\
35.2 \\
35.2 \\
35.3 \\
36.3 \\
36.3 \\
38.0 \\
38.5 \\
38.5 \\
40.7 \\
41.4 \\
42.8 \\
429 \\
44.0 \\
46.0 \\
46.2 \\
64.8\end{array}$ & $\begin{array}{l}\text { MIN } \\
\text { AVG }\end{array}$ & 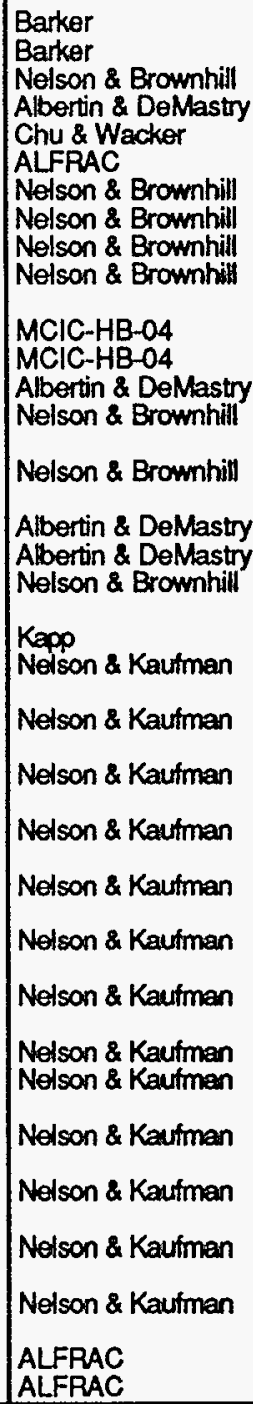 \\
\hline
\end{tabular}


TABLE 1. FRACTURE TOUGHNESS DATA FOR 6061-T6, 6061-T651, AND 6061-T652 ALUMINUM. (CONT.)

\begin{tabular}{|c|c|c|c|c|c|c|c|c|c|c|c|}
\hline Materlal & $\begin{array}{c}\text { Temp. } \\
\text { (C) }\end{array}$ & $\begin{array}{l}\text { Spocimen } \\
\text { Typo }\end{array}$ & $\begin{array}{c}\text { Specimen } \\
\text { Sizo } \\
(\mathrm{mm}) \\
\end{array}$ & $\begin{array}{l}\text { Crack } \\
\text { Orr. }\end{array}$ & $\begin{array}{c}\text { No. } \\
\text { of } \\
\text { Spec. }\end{array}$ & $\begin{array}{c}\mathrm{Kq} \\
(\mathrm{MPa} \sqrt{\mathrm{m}})\end{array}$ & $\frac{\mathrm{Kmax}}{(\mathrm{MPa} \sqrt{\mathrm{m}})}$ & $\begin{array}{c}K \mathrm{j} \\
\left(M P_{a} \sqrt{m}\right)\end{array}$ & $\begin{array}{c}K l_{c} \\
(M P a \sqrt{m})\end{array}$ & Notes & Reference \\
\hline 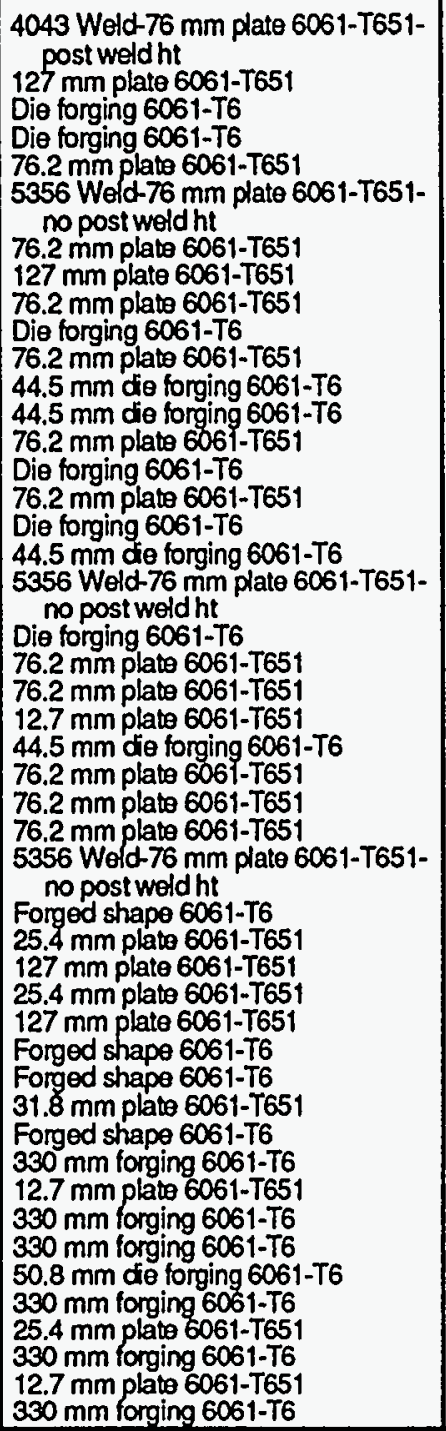 & $\begin{array}{l}22 \\
24 \\
24 \\
24 \\
22 \\
22 \\
22 \\
24 \\
24 \\
24 \\
22 \\
24 \\
24 \\
24 \\
24 \\
22 \\
24 \\
24 \\
22 \\
24 \\
22 \\
22 \\
24 \\
24 \\
22 \\
22 \\
24 \\
22 \\
24 \\
24 \\
24 \\
24 \\
24 \\
24 \\
24 \\
24 \\
24 \\
24 \\
24 \\
24 \\
24 \\
24 \\
24 \\
24 \\
24 \\
24 \\
24 \\
\end{array}$ & $\begin{array}{l}\text { Notch-bend } \\
\text { Compact } \\
\text { Compact } \\
\text { Compact } \\
\text { Notchbend } \\
\text { Notch-bend } \\
\text { Notch-bend } \\
\text { Compact } \\
\text { Compact } \\
\text { Compact } \\
\text { Notch-bend } \\
\text { Compact } \\
\text { Compact } \\
\text { Compact } \\
\text { Compact } \\
\text { Notch-bend } \\
\text { Compact } \\
\text { Compact } \\
\text { Notch-bend } \\
\text { Compact } \\
\text { Notch-bend } \\
\text { Notch-bend } \\
\text { Compact } \\
\text { Compact } \\
\text { Notch-bend } \\
\text { Notch-bend } \\
\text { Compact } \\
\text { Notch-bend } \\
\text { Compact } \\
\text { Compact } \\
\text { Compact } \\
\text { Compact } \\
\text { Compact } \\
\text { Compact } \\
\text { Compact } \\
\text { Compact } \\
\text { Compact } \\
\text { Compact } \\
\text { Compact } \\
\text { Compact } \\
\text { Compact } \\
\text { Compact } \\
\text { Compact } \\
\text { Compact } \\
\text { Compact } \\
\text { Compact } \\
\text { Compact }\end{array}$ & $\begin{array}{c}74 \\
50.83 \\
12.67 \\
12.70 \\
57.1 \\
73.2 \\
76.6 \\
63.50 \\
63.50 \\
12.70 \\
76.6 \\
31.72 \\
31.72 \\
74.75 \\
12.60 \\
76.6 \\
12.60 \\
31.75 \\
73.1 \\
12.70 \\
76.8 \\
57.2 \\
11.81 \\
31.75 \\
76.7 \\
76.7 \\
63.50 \\
72.9 \\
25.43 \\
24.4856 \\
63.50 \\
24.49 \\
63.50 \\
25.37 \\
25.37 \\
30.91 \\
25.40 \\
50.80 \\
11.81 \\
50.83 \\
50.83 \\
19.08 \\
550.77 \\
24.49 \\
50.80 \\
11.94 \\
31.83 \\
\end{array}$ & $\begin{array}{l}S L \\
T L \\
L T \\
T L \\
T \\
T L \\
T L \\
T L \\
T L \\
T L \\
T L \\
T L \\
L T \\
L T \\
T L \\
T L \\
L T \\
T \\
L T \\
L T \\
L T \\
L T \\
T L \\
L-T \\
L T \\
L T \\
L T \\
L T \\
T R \\
T R \\
T L \\
L T \\
T L \\
L T \\
R T \\
R T \\
L T \\
T R \\
L T \\
L T \\
L T \\
L T \\
C L \\
L T \\
L T \\
L T \\
T R \\
L T \\
\end{array}$ & $\begin{array}{l}1 \\
1 \\
1 \\
1 \\
1 \\
1 \\
1 \\
1 \\
1 \\
1 \\
1 \\
1 \\
1 \\
1 \\
1 \\
1 \\
1 \\
1 \\
1 \\
1 \\
1 \\
1 \\
1 \\
1 \\
1 \\
1 \\
1 \\
1 \\
1 \\
1 \\
1 \\
1 \\
1 \\
1 \\
1 \\
1 \\
1 \\
1 \\
1 \\
1 \\
1 \\
1 \\
1 \\
1 \\
1 \\
1 \\
1 \\
1 \\
1 \\
1 \\
\end{array}$ & $\begin{array}{l}27.6 \\
27.8 \\
23.0 \\
28.2 \\
28.8 \\
28.9 \\
29.0 \\
29.1 \\
29.2 \\
29.8 \\
29.8 \\
30.3 \\
30.4 \\
30.5 \\
30.7 \\
30.7 \\
30.8 \\
31.3 \\
32.0 \\
32.4 \\
32.5 \\
32.7 \\
33.1 \\
33.1 \\
33.3 \\
33.6 \\
34.5 \\
35.1 \\
35.1 \\
35.2 \\
35.4 \\
35.5 \\
35.6 \\
35.6 \\
35.6 \\
37.1 \\
37.4 \\
37.9 \\
38.8 \\
39.0 \\
39.2 \\
39.4 \\
39.7 \\
40.7 \\
40.9 \\
41.4 \\
41.6\end{array}$ & $\begin{array}{l}41.4 \\
37.9 \\
\\
41.0 \\
42.1 \\
55.6\end{array}$ & & & & 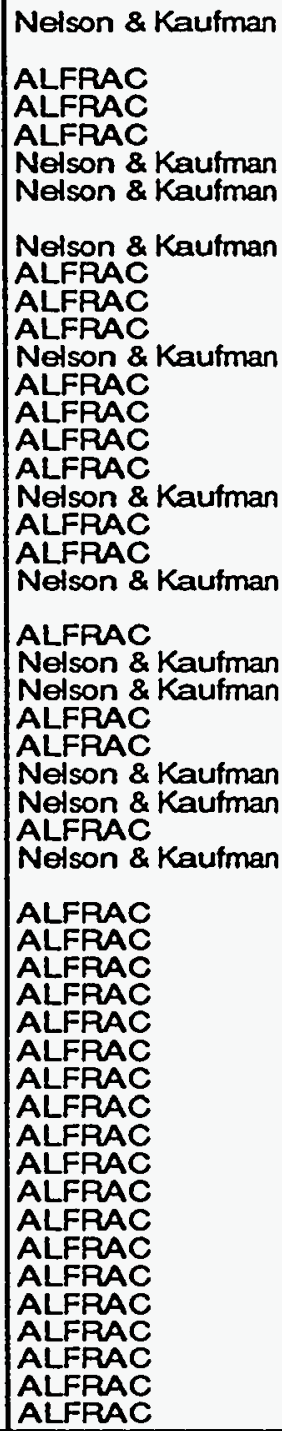 \\
\hline
\end{tabular}


TABLE 1. FRACTURE TOUGHNESS DATA FOR 6061-T6, 6061-T651, AND 6061-T652 ALUMINUM. (CONT.)

\begin{tabular}{|c|c|c|c|c|c|c|c|c|c|c|c|}
\hline Material & $\begin{array}{c}\text { Temp. } \\
\text { (C) }\end{array}$ & $\begin{array}{l}\text { Specimen } \\
\text { Typo }\end{array}$ & $\begin{array}{c}\text { Specimen } \\
\text { Sizo } \\
(\mathrm{mm}) \\
\end{array}$ & $\begin{array}{l}\text { Crack } \\
\text { Orr. }\end{array}$ & $\begin{array}{c}\text { No. } \\
\text { of } \\
\text { Spec. }\end{array}$ & $\frac{\mathrm{Kq}}{(M \mathrm{qa} \sqrt{\mathrm{m}})}$ & $\frac{\text { Kmax }}{(\operatorname{MPa} \sqrt{m})}$ & $\begin{array}{c}K \mathbf{J} \\
(\operatorname{MPa} \sqrt{\mathrm{m}})\end{array}$ & $\begin{array}{c}\text { Klc } \\
(M P a \sqrt{m})\end{array}$ & Notes & Referenco \\
\hline $\begin{array}{l}38.1 \mathrm{~mm} \text { plate } 6061-\mathrm{T} 651 \\
50.8 \mathrm{~mm} \text { die forging } 6061-\mathrm{T} 6 \\
25.4 \mathrm{~mm} \text { plate } 6061-\mathrm{T} 651 \\
330 \mathrm{~mm} \text { forging } 6061-\mathrm{T} 6 \\
12.7 \mathrm{~mm} \text { plate } 6061-\mathrm{T} 651 \\
38.1 \mathrm{~mm} \text { die forging } 6061-\mathrm{T} 6 \\
38.1 \mathrm{~mm} \text { die forging } 6061-\mathrm{T} 6 \\
229 \times 610 \times 610 \mathrm{~mm} \text { forging } 6061-\mathrm{T} 652 \\
229 \times 610 \times 610 \mathrm{~mm} \text { forging } 6061-\mathrm{T} 652 \\
229 \times 610 \times 610 \mathrm{~mm} \text { forging } 6061-\mathrm{T} 652 \\
229 \times 610 \times 610 \mathrm{~mm} \text { forging } 6061-\mathrm{T} 652 \\
229 \times 610 \times 610 \mathrm{~mm} \text { forging } 6061-\mathrm{T} 652 \\
229 \times 610 \times 610 \mathrm{~mm} \text { forging } 6061-\mathrm{T} 652 \\
152 \times 305 \times 610 \mathrm{~mm} \text { forging } 6061-\mathrm{T} 652 \\
19.0 \mathrm{~mm} \text { plate } 6061-\mathrm{T} 651 \\
19.0 \mathrm{~mm} \text { plate } 6061-\mathrm{T} 651 \\
19.0 \mathrm{~mm} \text { plate } 6061-\mathrm{T} 651 \\
19.0 \mathrm{~mm} \text { plate } 6061-\mathrm{T} 651 \\
19.0 \mathrm{~mm} \text { plate } 6061-\mathrm{T} 651 \\
19.0 \mathrm{~mm} \text { plate } 6061-\mathrm{T} 651 \\
19.0 \mathrm{~mm} \text { plate } 6061-\mathrm{T} 651 \\
19.0 \mathrm{~mm} \text { plate } 6061-\mathrm{T} 651 \\
19.0 \mathrm{~mm} \text { plate } 6061-\mathrm{T} 651 \\
19.0 \mathrm{~mm} \text { plate } 6061-\mathrm{T} 651 \\
6061-\mathrm{T} 651 \\
6061-\mathrm{T} 651 \text { plate } \\
6061-\mathrm{T} 651 \text { plate } \\
6061-\mathrm{T} 651 \text { plate }\end{array}$ & $\begin{array}{l}-196 \\
24 \\
24 \\
24 \\
24 \\
24 \\
24 \\
22 \\
22 \\
22 \\
22 \\
22 \\
22 \\
22 \\
21 \\
21 \\
26 \\
26 \\
95 \\
95 \\
95 \\
150 \\
150 \\
150 \\
24 \\
24 \\
24 \\
24\end{array}$ & $\begin{array}{l}\text { Compact } \\
\text { Compact } \\
\text { Compact } \\
\text { Compact } \\
\text { Compact } \\
\text { Compact } \\
\text { Nototh-bend } \\
\text { Notch-bend } \\
\text { Notth-bend } \\
\text { Notth-bend } \\
\text { Notch-bend } \\
\text { Notch-bend } \\
\text { Notch-bend } \\
\text { Compact } \\
\text { Compact } \\
\text { Compact } \\
\text { Compact } \\
\text { Compact } \\
\text { Compact } \\
\text { Compact } \\
\text { Compact } \\
\text { Compact } \\
\text { Compact } \\
\text { Compact } \\
\text { Procracked Charpy } \\
\text { Precracked Charpy } \\
\text { Procracked Charpy }\end{array}$ & $\begin{array}{l}19.05 \\
24.49 \\
50.80 \\
11.94 \\
19.08 \\
19.05 \\
76.2 \\
76.2 \\
76.2 \\
50.8 \\
50.8 \\
50.8 \\
76.2 \\
11.4 \\
11.4 \\
11.4 \\
11.4 \\
11.4 \\
11.4 \\
11.4 \\
11.4 \\
11.4 \\
11.4 \\
10.7\end{array}$ & $\begin{array}{l}W L \\
C L \\
L T \\
L T \\
L T \\
L C \\
L C \\
R T \\
R T \\
R W \\
W R \\
W R \\
W T \\
R T \\
T L \\
T L \\
T L \\
T L \\
T L \\
T L \\
T L \\
T L \\
T L \\
T L \\
L T\end{array}$ & $\begin{array}{l}1 \\
1 \\
1 \\
1 \\
1 \\
1 \\
1 \\
1 \\
1 \\
1 \\
1 \\
1 \\
1 \\
1 \\
1 \\
1 \\
1 \\
1 \\
1 \\
1 \\
1 \\
1 \\
1\end{array}$ & $\begin{array}{l}41.8 \\
42.2 \\
42.3 \\
43.0 \\
44.4 \\
45.6 \\
47.6\end{array}$ & $\begin{array}{l}47.5 \\
53.5 \\
40.9 \\
39.2 \\
39.1 \\
50.0 \\
72.4\end{array}$ & $\begin{array}{l}33.0 \\
33.8 \\
33.6 \\
321 \\
29.9 \\
30.8 \\
30.2 \\
32.3 \\
31.3 \\
32.6 \\
27.2 \\
53.8 \\
32.2 \\
35.2\end{array}$ & & $\begin{array}{l} \\
\\
\text { Max. } \\
\text { Max. } \\
\text { Max. }\end{array}$ & $\begin{array}{l}\text { ASMH } \\
\text { ALFRAC } \\
\text { ALFRAC } \\
\text { ALFRAC } \\
\text { ALFRAC } \\
\text { ALFRAC } \\
\text { ALFRAC } \\
\text { Chu \& Wacker } \\
\text { Chu \& Wacker } \\
\text { Chu \& Wacker } \\
\text { Chu \& Wacker } \\
\text { Chu \& Wacker } \\
\text { Chu \& Wacker } \\
\text { Chu \& Wacker } \\
\text { Alexander } \\
\text { Alexander } \\
\text { Alexander } \\
\text { Alexander } \\
\text { Alexander } \\
\text { Alexander } \\
\text { Alexander } \\
\text { Alexander } \\
\text { Alexander } \\
\text { Alexander } \\
\text { McConnell et al } \\
\text { Kapp } \\
\text { Succop \& Brown } \\
\text { Suocop \& Brown }\end{array}$ \\
\hline
\end{tabular}




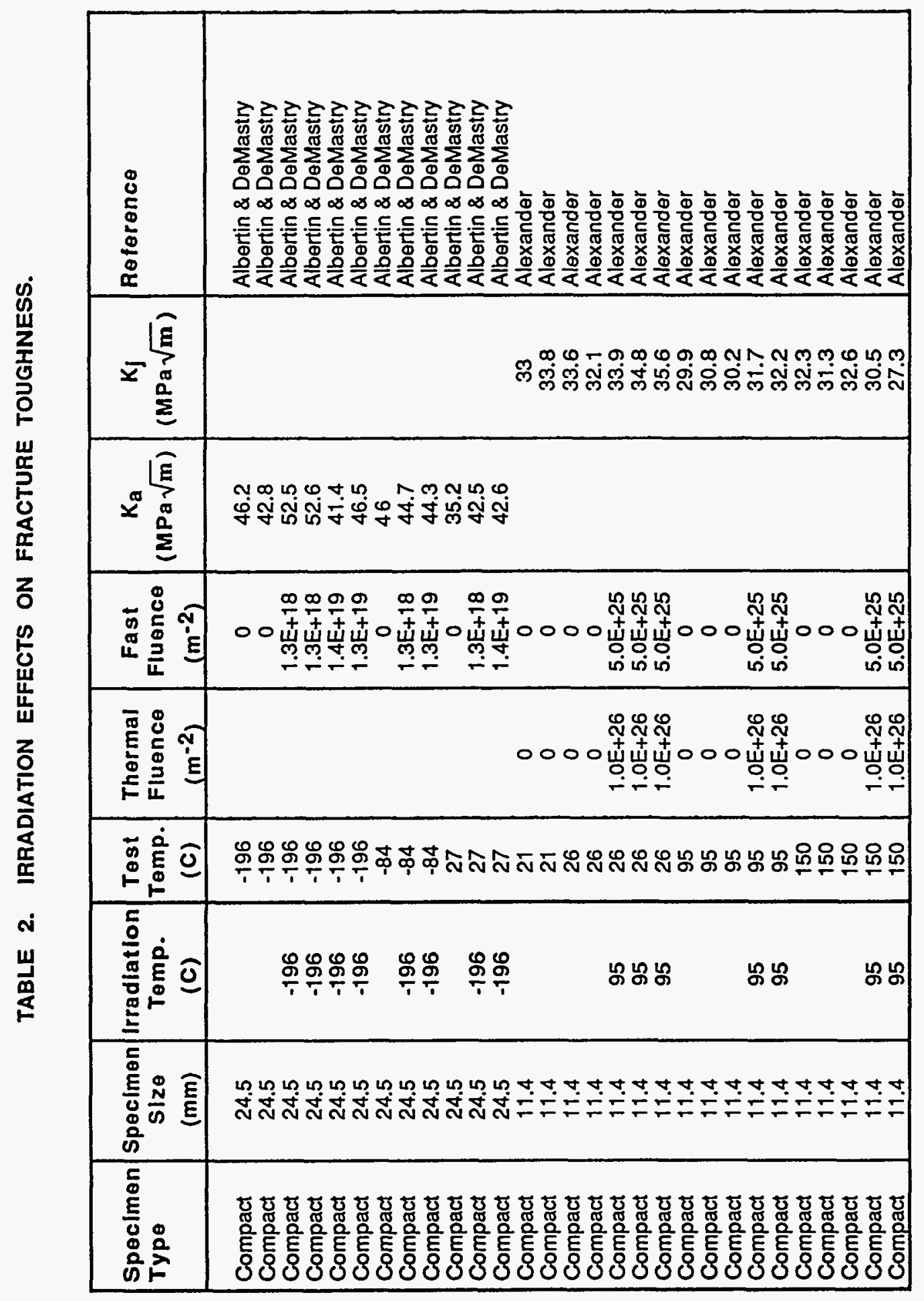




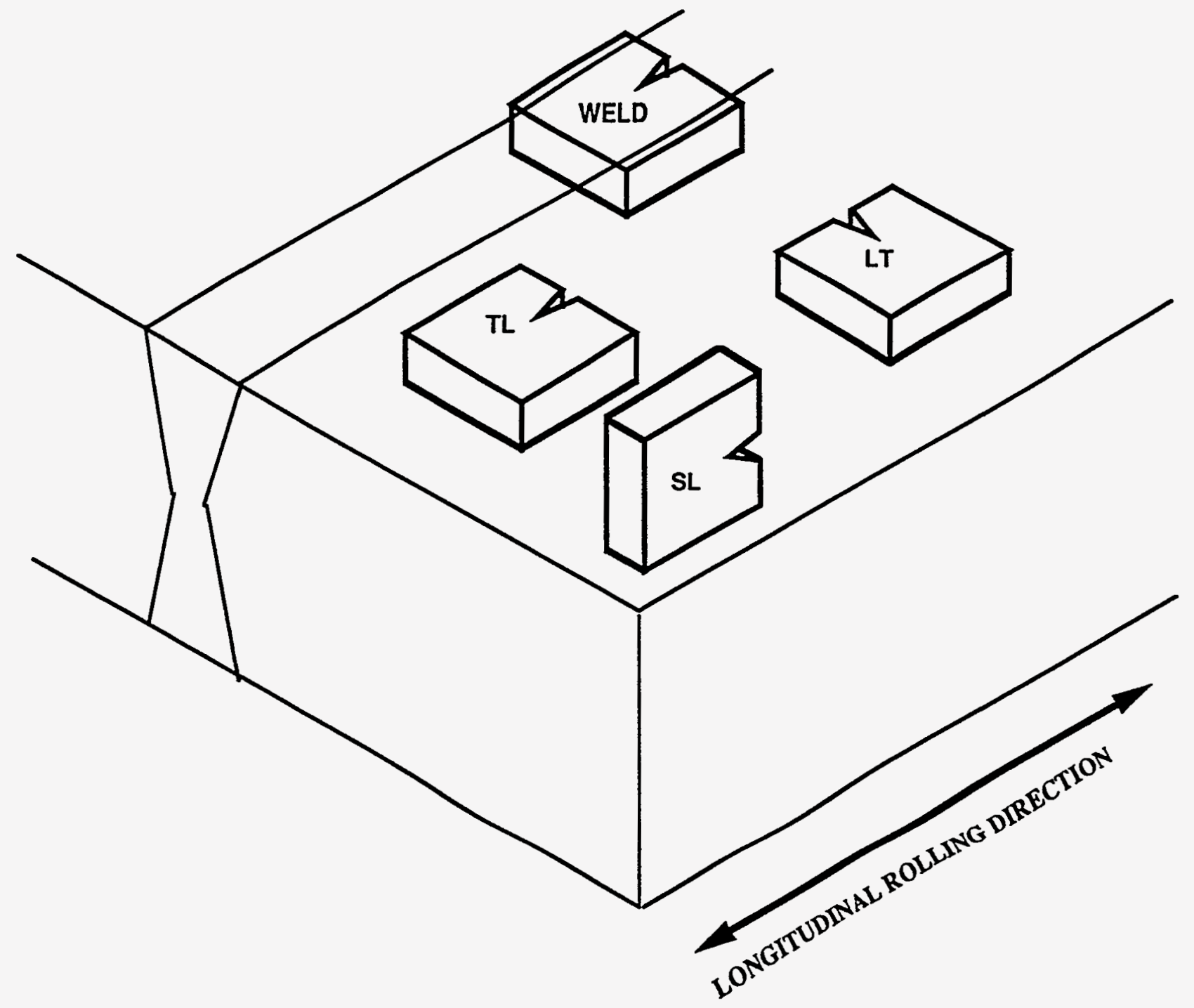

FIG. 1. CRACK ORIENTATIONS IN PLATES. 


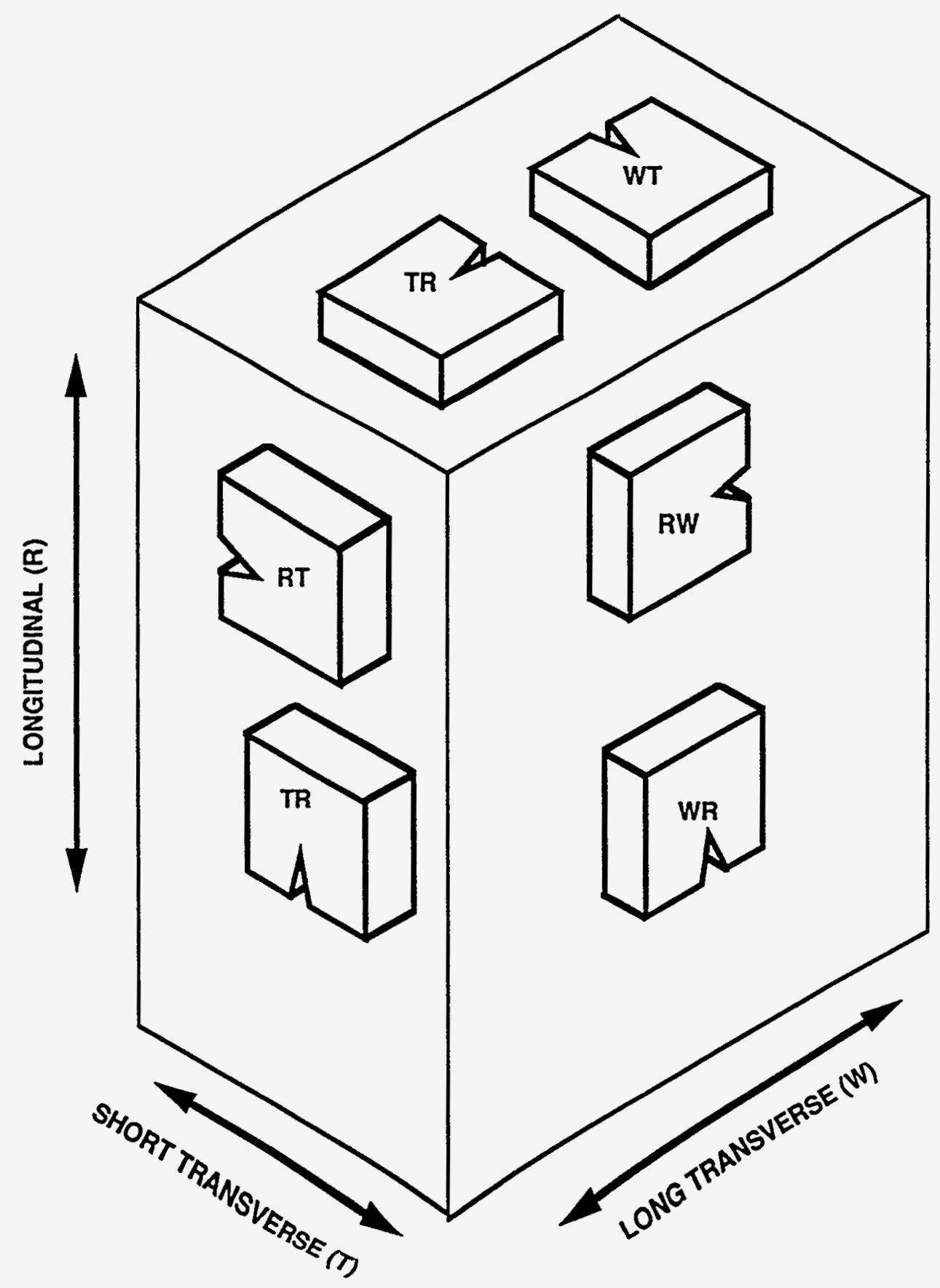

FIG. 2. CRACK ORIENTATIONS IN FORGINGS. 


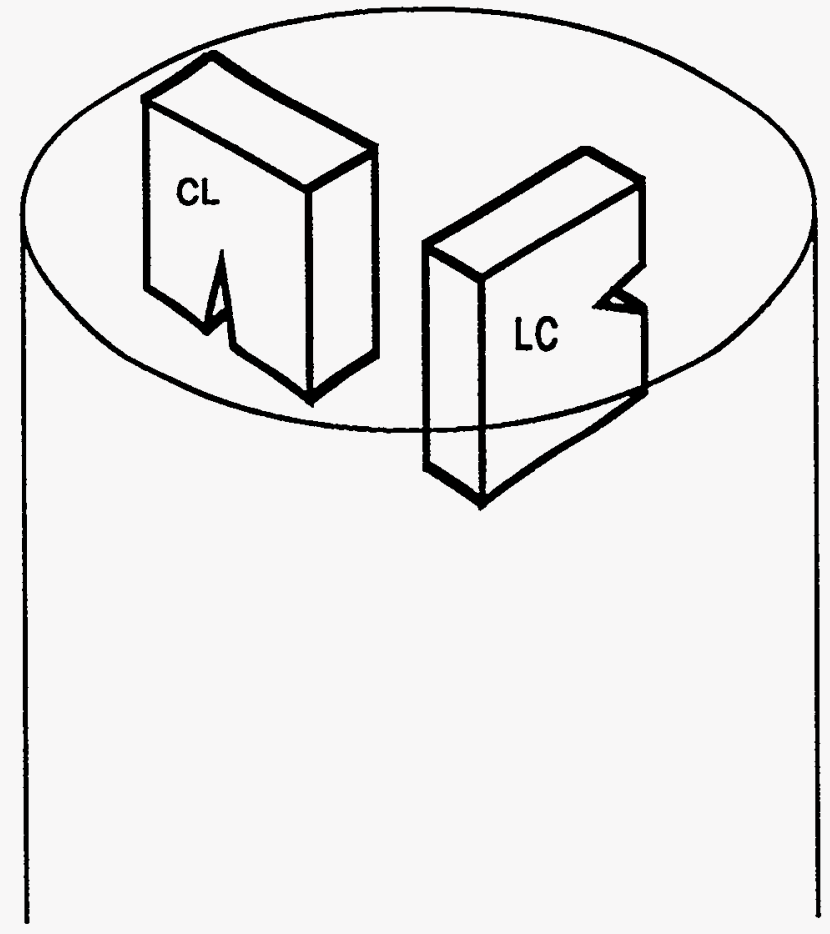

FIG. 3. CRACK ORIENTATIONS IN ROUND BARS. 